\title{
Evaluation and Rearrangement of Novel Supramolecular 7-(2,3-Dihydro- 1,3-benzothiazol-2-yl)quinolin-8-ol Complexes and their Biological Effect
}

\author{
El-Sonbati $\mathrm{AZ}^{1 *}$, Diab MA1, El-Bindary AA ${ }^{1}$, Nozha SG ${ }^{1}$ and Nassar MI $^{2}$
}

${ }^{1}$ Chemistry Department, Faculty of Science, Damietta University, Egypt

${ }^{2}$ Entomology Department, Faculty of Science, Cairo University, Giza, Egypt

\begin{abstract}
Novel tridentate Schiff base ligand derived from the 2-aminobenzenthiol and 8-hydroxy-7-quinolinecarboxaldehyde (oxine) and its metal complexes have been prepared. The reaction of a solution of 7-(2,3-dihydro-1,3-benzothiazol2-yl)quinolin-8-ol $\left(\mathrm{H}_{2} \mathrm{~L}\right)$ with di-and tetravalent transition metals have been studied chemically and biologically. The optimized bond lengths, bond angles and calculated the quantum chemical parameters for the ligand $\left(\mathrm{H}_{2} \mathrm{~L}\right)$ [the cyclic form (A) and the Schiff base form (B)] were investigated. The complexes have been characterized by elemental analyses, IR spectra, thermal analyses and ${ }^{1} \mathrm{H}$-NMR spectroscopy. The spectral studies of the isolated complexes showed that the rearrangement of the benzothiazoline to the Schiff base had occurred. The data suggest that the $\mathrm{Co}(\mathrm{II})$ and $\mathrm{Ni}$ (II) complexes are binuclear and octahedral dimmers, while the rest are monomeric with square planar/ tetrahedral geometries. The ESR spectrum of the $\mathrm{Cu}(\mathrm{II})$ complex show axial type symmetry with $\mathrm{g}_{\| 1}>\mathrm{g} \perp>2.002$, indicating $d_{x 2-y_{2}}$ ground state with significant covalent bond character. Five doses were topically applied against the newly emerged adults of the red palm weevil Rhynchophorus ferrugineus. Percent of adult mortality was $98.2 \%$, which occurred after adult treatment with the highest dose $(2.2 \mathrm{mg} / \mathrm{ml})$ of $\mathrm{Ni}(\mathrm{II})$ complex. The lowest mortality was $5.6 \%$ which obtained due to effect of oxine after adult was treated with dose of $0.25 \mathrm{mg} / \mathrm{ml}$. Five doses were topically applied against the newly emerged adults of the stored product weevil, Sitophilus granaria. While the lower mortality, $5 \%$ caused due to effect of least dose, $0.15 \mathrm{mg} / \mathrm{ml}$ of the compound oxine.
\end{abstract}

Keywords: 2-Aminobenzenethiol; Biological effect; Quantum chemical parameters; Schiff base; Supramolecular structure; ESR; Molecular structures

\section{Introduction}

Schiff bases continue to occupy an important position as ligands in metal coordination chemistry even after almost a century since their discovery. Sulphur and nitrogen have long been used to increase the biological activity of organic moiety $[1,2]$ and quinoline compounds have also found applications in medicinal chemistry [3]. However, no systematic study has been performed on such complexes.

It has been well established that condensation of 2-aminobenzenthiol with carbonyl compound does not normally lead to the isolation of the corresponding Schiff base, but thiazoline or benzothiazoline is obtained [4]. However, metal ions may act as a template and favor the formation of Schiff base.

Schiff bases are some of the most widely used organic compounds. They are used as pigments and dyes, catalysts, intermediates in organic synthesis and as polymer stabilizers $[5,6]$. Schiff bases have also been shown to exhibit a broad range of biological activities, including antifungal, antibacterial, antimalarial, antiproliferative, antiinflammatory, antiviral, and antipyretic properties [2,5]. It has been suggested that azomethine linkage $(\mathrm{C}=\mathrm{N})$ might be responsible for the biological activities of Schiff bases.

Studies of the complexing ability and analytical applications of heterocyclic azomethines derived from thiazoline compounds are very important [7-9]. It is well known that some drugs have increased activity when administered as metal complexes and number of metal chelates inhibit tumor growth [10].

The number and diversity of nitrogen and oxygen chelating agents used to prepare new coordination and organometallic compounds has increased rapidly recently [11-13].

The behavior of the $\mathrm{C}=\mathrm{N}$ bond is strongly dependent on the structure of the amine moiety, which in turn controls the efficiency of the conjugation and may incorporate structural elements able to modulate the steric crowding around the coordination [14].

The Red palm weevil Rhynchophorus ferruginous oliv. ColeopteraCurculionidae is a devastating insect pest of date palm in the Arabian Gulf region [15]. It was reported on date palm, for the first time, from the United Arab Emirates in the mid-1980s then its reported distributed expanded its range westwards till reached the entire Gulf area [16,17].

A survey of literature reveals that no work has been carried out on the synthesis of 7-(2,3-dihydro-1,3-benzothiazol-2-yl)quinolin-8-ol $\left(\mathrm{H}_{2} \mathrm{~L}\right)$ ligand and its $\mathrm{Cu}(\mathrm{II}), \mathrm{Co}(\mathrm{II}), \mathrm{Ni}(\mathrm{II}), \mathrm{Zn}(\mathrm{II}), \mathrm{Cd}(\mathrm{II})$ and $\mathrm{Zr}(\mathrm{IV})$ complexes. The present work aims at highlighting the synthesis and characterization of novel supramolecular chemistry of complexes with $\mathrm{H}_{2} \mathrm{~L}$ and studies their spectral properties. Molecular and electronic structures of the investigated ligand $\left(\mathrm{H}_{2} \mathrm{~L}\right)$ have been discussed. The effect of the ligand and its complexes on the red palm weevil Rhynchophorus ferrugineus (Oliv.) and on the stored food weevils Sitophilus granary were studied.

\section{Experimental}

All chemicals were reagent grade (BDH Chemical Ltd.) and were

*Corresponding author: El-Sonbati AZ, Chemistry Department, Faculty of Science, Damietta University, Damietta 34517, Egypt, Tel.: +201060081581; Fax: +20 572403868; E-mail: elsonbatisch@yahoo.com

Received July 28, 2014; Accepted August 12, 2014; Published August 19, 2014

Citation: El-Sonbati AZ, Diab MA, El-Bindary AA, Nozha SG, Nassar MI (2014) Evaluation and Rearrangement of Novel Supramolecular 7-(2,3-Dihydro-1,3benzothiazol-2-yl)quinolin-8-ol Complexes and their Biological Effect. J Microbial Biochem Technol S4: 001. doi:10.4172/1948-5948.S4-001

Copyright: (c) 2014 El-Sonbati AZ, et al. This is an open-access article distributed under the terms of the Creative Commons Attribution License, which permits unrestricted use, distribution, and reproduction in any medium, provided the original author and source are credited 
Citation: El-Sonbati AZ, Diab MA, El-Bindary AA, Nozha SG, Nassar MI (2014) Evaluation and Rearrangement of Novel Supramolecular 7-(2,3-Dihydro1,3-benzothiazol-2-yl)quinolin-8-ol Complexes and their Biological Effect. J Microbial Biochem Technol S4: 001. doi:10.4172/1948-5948. S4-001

used as supplied. The experimental techniques were as described previously [18-20]. 8-Hydroxy-7-quinoline carboxaldehyde (oxine) was previously prepared by El-Sonbati [21].

\section{Preparation of 7-(2,3-dihydro-1,3-benzothiazol-2-yl) quinolin-8-ol $\left(\mathrm{H}_{2} \mathrm{~L}\right)$}

A solution of 8-hydroxy-7-quinolinecarboxaldehyde (oxine) $(0.06$ mol) in DMF:Ethanol (15 ml) was treated with 2-aminobenzenethiol $(0.06 \mathrm{~mol})$ in ethanol $(15 \mathrm{ml})$ (Scheme 1$)$. The reaction was refluxed for $3.5 \mathrm{hrs}$. The pale brown precipitate formed was purified by recrystallization from hot ethanol. Yield 55\%, (Found: C 68.4, H 4.1, $\mathrm{N}$ 9.6, S 11.1\% Calculated for $\mathrm{C}_{16} \mathrm{H}_{12} \mathrm{~N}_{2} \mathrm{SO}$ : C 68.6, H 4.3, N 10.0, S $11.4 \%)$. The purity was checked by elemental analyses, IR and ${ }^{1} \mathrm{H}$ NMR spectroscopies.

\section{Oxidation of 7-(2,3-dihydro-1,3-benzothiazol-2-yl)quinolin- 8-ol $\left(\mathrm{H}_{2} \mathrm{~L}\right)$}

Oxidation was carried out by bubbling air for four hrs in benzene solution of 7-(2,3-dihydro-1,3-benzothiazol-2-yl)quinolin-8-ol $\left(\mathrm{H}_{2} \mathrm{~L}\right)$. The oxidation product was benzothiazol. Found C, 68.87; H, 3.50; N, 9.77; S, 11.51\%. Calculated for $\mathrm{C}_{16} \mathrm{H}_{10} \mathrm{~N}_{2} \mathrm{SO} ; \mathrm{C}, 69.07 ; \mathrm{H}, 3.61 ; \mathrm{N}, 10.07$; $\mathrm{S}, 11.37 \%$. No band was observed in the IR spectrum above $3130 \mathrm{~cm}^{-1}$, indicating the absence of $\mathrm{NH}$.

\section{General method for preparing complexes}

Reaction of 7-(2,3-dihydro-1,3-benzothiazol-2-yl)quinolin-8ol with metal ions: The complexes were prepared by methods similar to the reported in earlier publications [14,22-24] according to the following procedures:<smiles>Nc1ccccc1N</smiles><smiles>Nc1ccccc1/N=C/c1ccc2cccnc2c1O</smiles>

(B)<smiles>Oc1c(-c2nc3ccccc3s2)ccc2cccnc12</smiles>

(D)<smiles></smiles>

(E)
Cyclic form

(A)

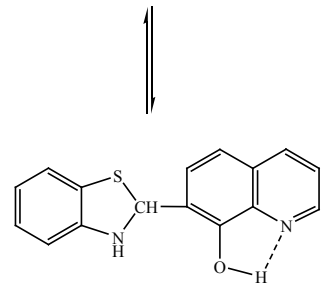

(C)<smiles>Oc1c(C2Nc3ccccc3S2)ccc2cccnc12</smiles>

Scheme 1: Synthetic routes for the preparation of tautomeric forms of 7-(2,3-dihydro-1,3-benzothiazol-2-yl)quinolin-8-ol $\left(\mathrm{H}_{2} \mathrm{~L}\right)$.

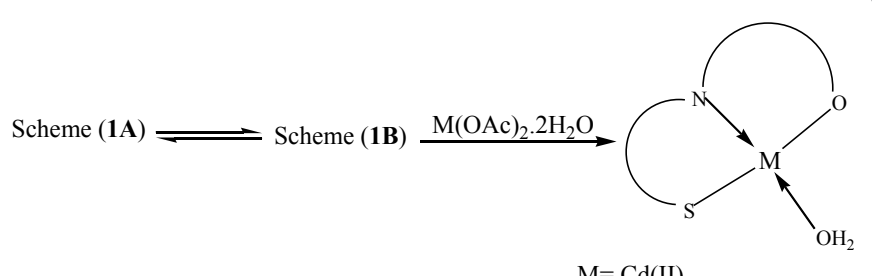

$\mathrm{M}=\mathrm{Cd}(\mathrm{II})$

(I)

$=\mathrm{Zn}(\mathrm{II})$

(II)

Scheme 2: The structure of complexes (I,II)

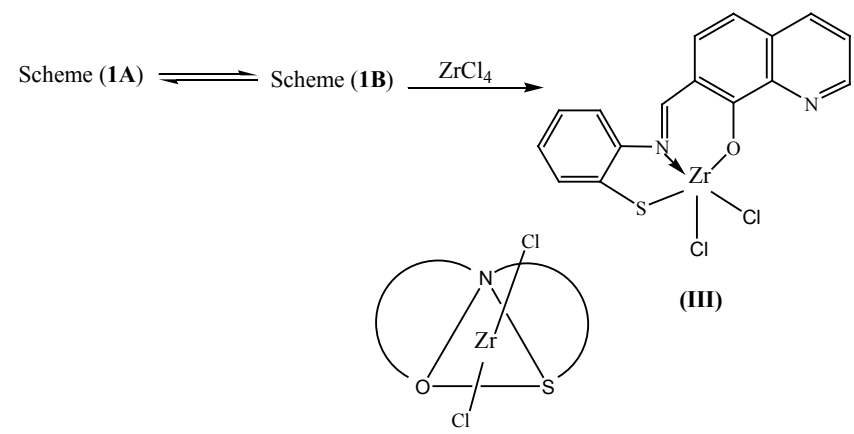

Scheme 3: The structure of complex (III).

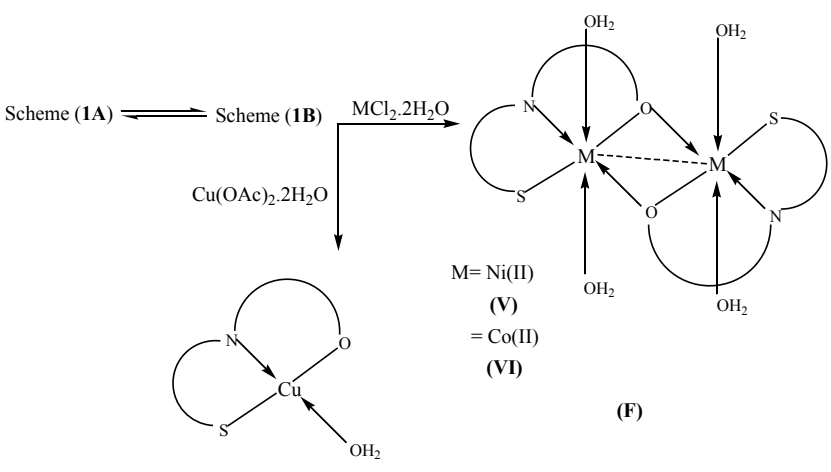

(IV)

(G)

Scheme 4: The structure of complexes (IV-VI).

1) Mono(7-(2,3-dihydro-1,3-benzothiazol-2-yl)quinolin-8-ol)Cd and $\mathrm{Zn}[(\mathrm{I})$ and $(\mathrm{II})]$ (Scheme 2$)$

$\mathrm{M}(\mathrm{OAc})_{2} .2 \mathrm{H}_{2} \mathrm{O}(0.5 \mathrm{mmol})$ in ethanol $(15 \mathrm{ml})$, was added to ligand $\left(\mathrm{H}_{2} \mathrm{~L}\right)(0.5 \mathrm{mmol})$ in DMF:Ethanol $(1: 2 \mathrm{v} / \mathrm{v})(25 \mathrm{ml})$ and the resulting mixture was stirred at room temperature for $3 \mathrm{~h}$. The formed precipitate was filtered off, washed with ethanol and ether, respectively, and dried in vacuum over $\mathrm{P}_{2} \mathrm{O}_{5}$.

2) Chloro(7-(2,3-dihydro-1,3-benzothiazol-2-yl)quinolin-8-ol) zirconium [(III)] (Scheme 3)

Solution of $\mathrm{ZrCl}_{4}(1 \mathrm{mmol})$ and the ligand $\left(\mathrm{H}_{2} \mathrm{~L}\right)(1 \mathrm{mmol})$ in DMF:Methanol (1:2 v/v) $(45 \mathrm{ml})$ was mixed and stirred for $4 \mathrm{~h}$. The obtained precipitate was filtered, washed with $\mathrm{MeOH}$ and dried in vacuum over $\mathrm{P}_{2} \mathrm{O}_{5}$. 
Citation: El-Sonbati AZ, Diab MA, El-Bindary AA, Nozha SG, Nassar MI (2014) Evaluation and Rearrangement of Novel Supramolecular 7-(2,3-Dihydro1,3-benzothiazol-2-yl)quinolin-8-ol Complexes and their Biological Effect. J Microbial Biochem Technol S4: 001. doi:10.4172/1948-5948. S4-001

Page 3 of 9

3) $\operatorname{Bi}(7-(2,3-$ dihydro-1,3-benzothiazol-2-yl)quinolin-8-ol) $\mathrm{Cu} / \mathrm{Ni} /$ Co [IV-VI)] (Scheme 4)

The reaction of the ligand with $\mathrm{MX}_{2} \cdot \mathrm{nH}_{2} \mathrm{O}$ was carried out by stirring a mixture of DMF:Ethanol solutions of the ligand and the $\mathrm{MX}_{2}$. $\mathrm{nH}_{2} \mathrm{O}$ for four hours at room temperature. The obtained product was filtered off and washed with ethanol, then dried in vacuum over $\mathrm{P}_{2} \mathrm{O}_{5}$.

\section{Insect rearing}

Colonies of Rhynchophorus ferrugineus are serious pest of coconut causing damage and often killing the plam in its prime of life. The hatched grubs burrow into the trunk and feed on tissue of the stem. In the present study, the adult, larvae and pupal stages were collected from large cavities of infested date trees from Nagran region in KSA particularly for those received no chemical insecticides. Laboratory culture of Rhynchophorus ferrugineus was established under $26 \pm 2^{\circ} \mathrm{C}$ and $60 \pm 5 \%$ R.H. Insect was feed on the freshly shred sugar-cane stem tissues. The colony was checked daily for the deposited eggs between sugar-cane tissues and changed when becoming moldy. The sugar-cane pieces on which the adults laid their eggs were transferred to small plastic cages until hatching. The newly hatched larvae were cultured on a medium consisting of sugar-cane shreds.

\section{Bioassay of inorganic chemical compounds}

Five concentrations of oxine, $\mathrm{H}_{2} \mathrm{~L}$ (Scheme 1B) and complexes $(\mathrm{IV}, \mathrm{V})$ (Scheme 4) were prepared by using Dimethylsulfoxide (DMSO) as solvent: $2.25,1.12,0.56,0.25$, and $0.125 \mathrm{mg} / \mathrm{ml}$. Four replicates contained (5 last larval instars each) for each concentration. The adults of Rhynchophorus ferrugineus were topically received $3 \mu$ for each concentration using Transferrepette-micropipette for the treatments. Also the control experiments were conducted by four replicates and the adults were topically treated with Dimethylsulfoxide (DMSO) as solvent only. All treated and control insects were kept at $26 \pm 2{ }^{\circ} \mathrm{C}$ and $60 \pm 5 \%$ R.H.

\section{Criteria studied and statistical analysis}

The adult mortalities were observed during $24 \mathrm{~h}$. Data obtained were analyzed using t-distribution and refined by Bessel correction [17].

\section{Measurements}

Microanalysis of all samples was carried out at King Khalid University Analytical Center, Saudi Arabia, using a Perkin-Elmer 2400 Series II Analyzer. The metal content in these complexes were estimated by standard methods [25]. IR spectra were recorded on a Perkin-Elmer 1340 spectrophotometer. Ultraviolet-Visible (UV-Vis) spectra of the compounds were recorded in Nuzol solution using a Unicom SP 8800 spectrophotometer. Magnetic measurements were carried out at room temperature using Gouy's method, employing $\mathrm{Hg}\left[\mathrm{Co}(\mathrm{SCN})_{4}\right]$ for calibration purposes, and were corrected for diamagnetism by using Pascal's constant. Magnetic moments were calculated using the equation: $\mu_{\text {eff }}=2.84\left[\mathrm{~T}_{\mathrm{M}}{ }^{\text {coor. }}\right]^{1 / 2} .{ }^{1} \mathrm{H}$ NMR spectra obtained on JEOL FX900 Q Fourier transform spectrometer with $\mathrm{d}_{6}-\mathrm{DMSO}$ as solvent and TMS as internal reference. Thermogravimetric analysis (TGA) measurements were made using a DuPont 950 thermobalance. Ten milligram samples were heated at $10 \%$ min in a dynamic nitrogen atmosphere $(70 \mathrm{ml} /$ $\mathrm{min})$; the sample holder was boat-shaped, $10 \times 5 \times 2.5 \mathrm{~mm}$ deep; the temperature measuring thermocouple was placed within $1 \mathrm{~mm}$ of the holder. The halogen content was determined by combustion of the solid complex $(30 \mathrm{mg})$ in an oxygen flask in the presence of a $\mathrm{KOH}$ $\mathrm{H}_{2} \mathrm{O}_{2}$ mixture. The halide content was then determined by titration with a standard $\mathrm{Hg}\left(\mathrm{NO}_{3}\right)_{2}$ solution using diphenyl carbazone as an indicator. The molecular structures of the investigated compounds were optimized by HF method with 3-21G basis set. The molecules were built with the Perkin Elmer ChemBio Draw and optimized using Perkin Elmer ChemBio3D software [26]. Quantum chemical parameters such as the highest occupied molecular orbital energy $\left(\mathrm{E}_{\mathrm{HOMO}}\right)$, the lowest unoccupied molecular orbital energy $\left(\mathrm{E}_{\mathrm{LUMO}}\right)$ and HOMO-LUMO energy gap $(\Delta \mathrm{E})$ for the investigated molecules were calculated.

\section{Results and Discussion}

The ligand 7-(2,3-dihydro-1,3-benzothiazol-2-yl)quinolin-8ol $\left(\mathrm{H}_{2} \mathrm{~L}\right)$ is shown in Scheme 1. The optimized structures of cyclic form (A) and Schiff base form (B) are given in Figure 1. The selected geometrical structures of the investigated ligand $\left(\mathrm{H}_{2} \mathrm{~L}\right)$ [cyclic form (A) and the Schiff base form (B)] were calculated by optimizing their bond lengths and bond angles and listed in Tables 1 and 2. From Table 3 the computed net charges on active centers, it is found that the most negative charges in Schiff base form (B) and cyclic form (A) are N3 and S20.

Both the highest occupied molecular orbital (HOMO) and lowest unoccupied molecular orbital (LUMO) are the main orbital takes

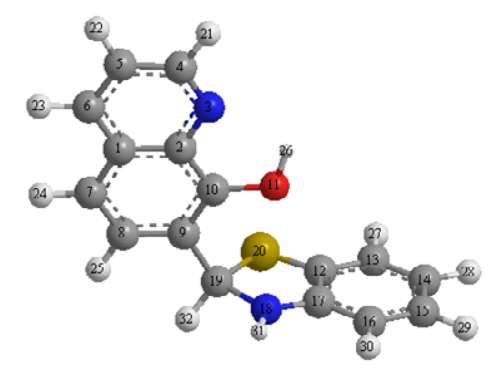

Cyclic form
(A)

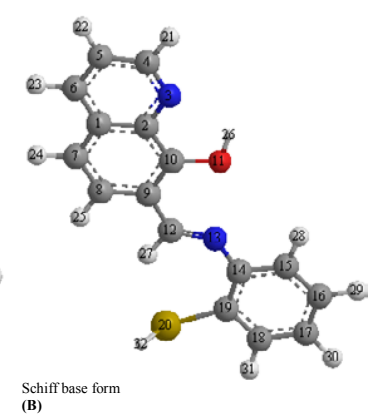

Schiff
(B)
Figure 1: Geometry optimized structures of $\mathrm{H}_{2} \mathrm{~L}$
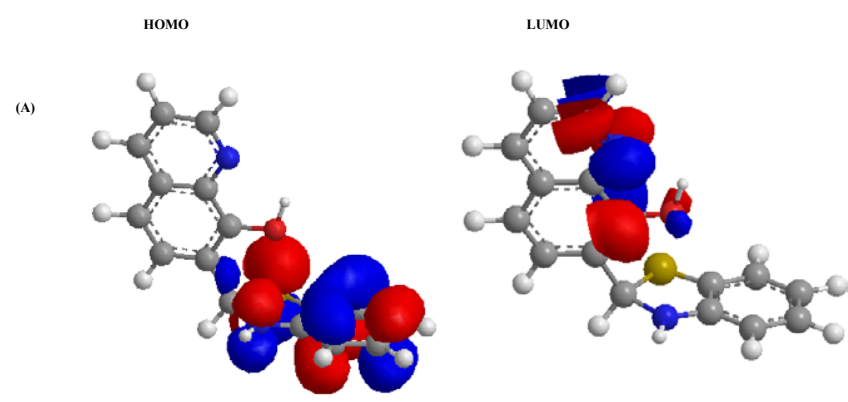

(B)
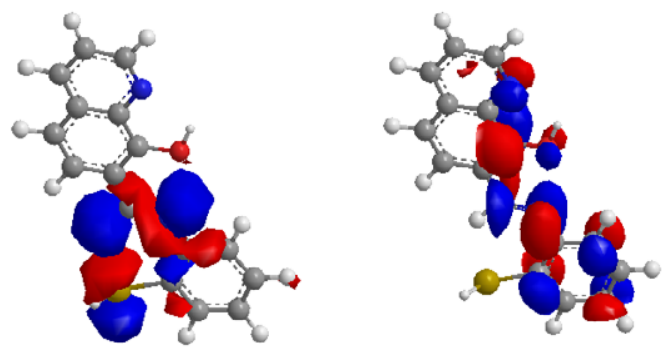

Figure 2: $\mathrm{HOMO}$ and LUMO molecular orbital of $\mathrm{H}_{2} \mathrm{~L}$ [cyclic form (A) and Schiff base form $(B)]$. 
Citation: El-Sonbati AZ, Diab MA, El-Bindary AA, Nozha SG, Nassar MI (2014) Evaluation and Rearrangement of Novel Supramolecular 7-(2,3-Dihydro1,3-benzothiazol-2-yl)quinolin-8-ol Complexes and their Biological Effect. J Microbial Biochem Technol S4: 001. doi:10.4172/1948-5948. S4-001

Page 4 of 9

\begin{tabular}{|c|c|c|c|}
\hline \multicolumn{4}{|c|}{ Bond lengths (A) } \\
\hline \multicolumn{2}{|c|}{ Cyclic form (A) } & \multicolumn{2}{|c|}{ Schiff base form (B) } \\
\hline $\mathrm{C} 19-\mathrm{H} 32$ & 1.113 & $\mathrm{~S} 20-\mathrm{H} 32$ & 1.346 \\
\hline N18-H31 & 1.047 & N18-H31 & 1.104 \\
\hline $\mathrm{C} 16-\mathrm{H} 30$ & 1.102 & $\mathrm{C} 17-\mathrm{H} 30$ & 1.103 \\
\hline $\mathrm{C} 15-\mathrm{H} 29$ & 1.103 & $\mathrm{C} 16-\mathrm{H} 29$ & 1.103 \\
\hline $\mathrm{C} 14-\mathrm{H} 28$ & 1.103 & $\mathrm{C} 15-\mathrm{H} 28$ & 1.106 \\
\hline $\mathrm{C} 13-\mathrm{H} 27$ & 1.104 & $\mathrm{C} 12-\mathrm{H} 27$ & 1.093 \\
\hline $\mathrm{O} 11-\mathrm{H} 26$ & 0.97 & $\mathrm{O} 11-\mathrm{H} 26$ & 0.97 \\
\hline $\mathrm{C} 8-\mathrm{H} 25$ & 1.103 & $\mathrm{C} 8-\mathrm{H} 25$ & 1.104 \\
\hline $\mathrm{C} 7-\mathrm{H} 24$ & 1.103 & $\mathrm{C} 7-\mathrm{H} 24$ & 1.103 \\
\hline $\mathrm{C} 6-\mathrm{H} 23$ & 1.102 & $\mathrm{C} 6-\mathrm{H} 23$ & 1.102 \\
\hline $\mathrm{C} 5-\mathrm{H} 22$ & 1.102 & $\mathrm{C} 5-\mathrm{H} 22$ & 1.102 \\
\hline $\mathrm{C} 4-\mathrm{H} 21$ & 1.103 & $\mathrm{C} 4-\mathrm{H} 21$ & 1.103 \\
\hline C4-N3 & 1.264 & C14-C19 & 1.354 \\
\hline C2-N3 & 1.269 & C18-C19 & 1.347 \\
\hline $\mathrm{C} 1-\mathrm{C} 2$ & 1.347 & C17-C18 & 1.34 \\
\hline $\mathrm{C} 10-\mathrm{C} 2$ & 1.35 & $\mathrm{C} 16-\mathrm{C} 17$ & 1.338 \\
\hline C9-C10 & 1.351 & C15-C16 & 1.341 \\
\hline C8-C9 & 1.345 & C14-C15 & 1.354 \\
\hline $\mathrm{C} 7-\mathrm{C} 8$ & 1.34 & C4-N3 & 1.264 \\
\hline $\mathrm{C} 1-\mathrm{C} 7$ & 1.342 & C2-N3 & 1.269 \\
\hline C6-C1 & 1.344 & C1-C2 & 1.347 \\
\hline C5-C6 & 1.34 & C10-C2 & 1.351 \\
\hline C4-C5 & 1.34 & C9-C10 & 1.353 \\
\hline C12-C17 & 1.346 & C8-C9 & 1.348 \\
\hline N18-C17 & 1.268 & C7-C8 & 1.34 \\
\hline C16-C17 & 1.34 & $\mathrm{C} 1-\mathrm{C} 7$ & 1.341 \\
\hline C15-C16 & 1.343 & $\mathrm{C} 6-\mathrm{C} 1$ & 1.344 \\
\hline C14-C15 & 1.344 & C5-C6 & 1.34 \\
\hline C13-C14 & 1.344 & C4-C5 & 1.34 \\
\hline C12-C13 & 1.342 & C19-S20 & 1.832 \\
\hline S20-C12 & 1.474 & C14-N13 & 1.273 \\
\hline C19-S20 & 1.792 & C12-N13 & 1.264 \\
\hline N18-C19 & 1.473 & C9-C12 & 1.353 \\
\hline C19-C9 & 1.514 & & \\
\hline
\end{tabular}

Table 1: Bond lengths for the cyclic form and Schiff base form.

part in chemical stability. The HOMO represents the ability to donate an electron, LUMO as an electron acceptor represents the ability to obtain an electron. The HOMO and LUMO for cyclic form (A) and Schiff base form (B) are shown in Figure 2. The calculated quantum chemical parameters are given in Table 4. Additional parameters such as $\Delta \mathrm{E}$, absolute electronegativities, $\chi$, chemical potentials, $\mathrm{Pi}$, absolute hardness, $\eta$, absolute softness, $\sigma$, global electrophilicity, $\omega$, global softness, $\mathrm{S}$, and additional electronic charge, $\Delta \mathrm{N}_{\max }$, have been calculated according to the following equations [27-29]:

$$
\begin{aligned}
& \Delta E=E_{\text {LUMO }}-E_{\text {HOMO }} \\
& \chi=\frac{-\left(E_{\text {HOMO }}+E_{\text {LUMO }}\right)}{2} \\
& \eta=\frac{E_{\text {LUMO }}-E_{\text {HOMO }}}{2} \\
& \sigma=\frac{1}{\eta}
\end{aligned}
$$$$
P i=-\chi
$$

$$
\begin{aligned}
& S=\frac{1}{2 \eta} \\
& \omega=\frac{P i^{2}}{2 \eta} \\
& \Delta N_{\text {max }}=-\frac{P i}{\eta}
\end{aligned}
$$

The HOMO-LUMO energy gap, $\Delta \mathrm{E}$, which is an important stability index, is applied to develop theoretical models for explaining the structure and conformation barriers in many molecular systems [26-29]. The value of $\Delta \mathrm{E}$ for Schiff base form (B) and cyclic form (A) was found 0.038 and 0.119 a.u., respectively, so the Schiff base form (B) more stable and highly reactive than cyclic form (A).

\section{Structural of the ligand and complexes}

The reaction of oxine with 2-aminobenzenethiol afforded a product whose IR spectrum shows a band at $3300 \mathrm{~cm}^{-1}$ (assigned to $v \mathrm{NH}$ ) but no absorption at $2620 \mathrm{~cm}^{-1} v(\mathrm{SH})$. Thus the Schiff base (7-(2,3-dihydro1,3-benzothiazol-2-yl)quinolin-8-ol) $\left(\mathrm{H}_{2} \mathrm{~L}\right)(\mathrm{B})$ is ruled out. The sulphur atom of the thiol group tends to form another S-C bond.

Cyclization takes place with the resulting formation of a thiazoline. Complexes of the Schiff base with $\mathrm{Cu}(\mathrm{II}), \mathrm{Co}(\mathrm{II}), \mathrm{Ni}(\mathrm{II}), \mathrm{Zn}(\mathrm{II}), \mathrm{Cd}(\mathrm{II})$ and $\mathrm{Zr}(\mathrm{IV})$ have been isolated and characterized. The complexes formed are characterized with respect to its composition by elemental analysis and showed agreement with theoretical data. The elemental analysis data listed in Table 5.

The analytical data of the novel complexes prepared agree very well with the compositions $\left[\mathrm{M}(\mathrm{L})\left(\mathrm{OH}_{2}\right)_{\mathrm{n}}\right]$ (where $\mathrm{M}=\mathrm{Cd}(\mathrm{II}), \mathrm{Zn}(\mathrm{II})$, $\mathrm{Cu}(\mathrm{II})$ at $\mathrm{n}=1 ; \mathrm{M}=\mathrm{Co}(\mathrm{II}), \mathrm{Ni}(\mathrm{II})$ at $\mathrm{n}=2)$ and $\left[\mathrm{Zr}(\mathrm{L})(\mathrm{Cl})_{2}\right]$. This can be represented by the following equations:

$\mathrm{H}_{2} \mathrm{~L}+\mathrm{M}(\mathrm{OAc})_{2} \cdot 2 \mathrm{H}_{2} \mathrm{O} \rightarrow\left[\mathrm{M}(\mathrm{L})\left(\mathrm{OH}_{2}\right)\right]+2 \mathrm{CH}_{3} \mathrm{COOH}\{\mathrm{M}=\mathrm{Cd}(\mathrm{II})$ (I), $\mathrm{Zn}$ (II) (II)\}

$$
\begin{aligned}
& \mathrm{H}_{2} \mathrm{~L}+\mathrm{ZrCl}_{4} \cdot \mathrm{H}_{2} \mathrm{O} \rightarrow\left[\mathrm{Zr}(\mathrm{L}) \mathrm{Cl}_{2}\right]+2 \mathrm{HCl}(\mathrm{III}) \\
& \mathrm{H}_{2} \mathrm{~L}+\mathrm{Cu}(\mathrm{OAc})_{2} \cdot 2 \mathrm{H}_{2} \mathrm{O} \rightarrow\left[\mathrm{Cu}(\mathrm{L})\left(\mathrm{OH}_{2}\right)\right]+2 \mathrm{CH}_{3} \mathrm{COOH}(\mathrm{IV}) \\
& \mathrm{H}_{2} \mathrm{~L}+\mathrm{MCl}_{2} \cdot 2 \mathrm{H}_{2} \mathrm{O} \rightarrow\left[\mathrm{M}(\mathrm{L})\left(\mathrm{OH}_{2}\right)_{2}\right]+2 \mathrm{HCl}\{\mathrm{M}=\mathrm{Ni}(\mathrm{II})(\mathrm{V}), \mathrm{Co}(\mathrm{II})
\end{aligned}
$$$$
\text { (VI)\} }
$$

The effervescence of $\mathrm{HCl}$ and evolution of ethanolic acid during complex formation was assessed quantitatively by $\mathrm{pH}$ titration, a spot test, and by its characteristic odor.

\section{Spectral and thermal properties of the ligand and complexes}

The IR spectrum of $\mathrm{H}_{2} \mathrm{~L}$ exhibits the absence of the bands at $v(\mathrm{SH})$ $\left(2500-2600 \mathrm{~cm}^{-1}\right)$ and $v(\mathrm{C}=\mathrm{N})\left(1600-1660 \mathrm{~cm}^{-1}\right)$ and the appearance of a broad and strong band which is observed in the region, 3360-3060 $\mathrm{cm}^{-1}$. This band is attributed to $v(\mathrm{OH})$ and/or $v(\mathrm{NH})$. Also, an intense band at $828 \mathrm{~cm}^{-1}$ due to the $\mathrm{C}-\mathrm{S}-\mathrm{C}$ linkage and not Schiff base form [7]. Two bands of medium intensity at 1580 and $1505 \mathrm{~cm}^{-1}$ are attributed to thiazoline ring vibration (Table 6).

The ${ }^{1} \mathrm{H}$ NMR data of uncomplex and diamagnetic complexes [1820] have been listed in Table 7. The $\delta \mathrm{OH}(\sim 12.02 \mathrm{ppm})$ and $\delta \mathrm{NH}(4.18$ $\mathrm{ppm})$ proton signals are present in the ligand. These signals disappear upon addition of $\mathrm{D}_{2} \mathrm{O}$.

The phenyl protons are observed in the region $\delta 6.53-7.24 \mathrm{ppm}$ and proton due to $-\mathrm{CH}$ shows a marked downfield shift on complex 
Citation: El-Sonbati AZ, Diab MA, El-Bindary AA, Nozha SG, Nassar MI (2014) Evaluation and Rearrangement of Novel Supramolecular 7-(2,3-Dihydro1,3-benzothiazol-2-yl)quinolin-8-ol Complexes and their Biological Effect. J Microbial Biochem Technol S4: 001. doi:10.4172/1948-5948. S4-001

Page 5 of 9

\begin{tabular}{|c|c|c|c|c|c|c|c|}
\hline \multicolumn{4}{|c|}{ Cyclic form (A) } & \multicolumn{4}{|c|}{ Schiff base form (B) } \\
\hline \multicolumn{2}{|c|}{ Bond angles $\left({ }^{\circ}\right)$} & \multicolumn{2}{|c|}{ Dihedral angles $\left({ }^{\circ}\right)$} & \multicolumn{2}{|c|}{ Bond angles $\left({ }^{\circ}\right)$} & \multicolumn{2}{|c|}{ Dihedral angles $\left(^{\circ}\right)$} \\
\hline $\mathrm{H} 29-\mathrm{C} 15-\mathrm{C} 16$ & 119.758 & C17-N18-C19-C9 & 118.396 & H32-S20-C19 & 110.219 & N13-C14-C19-C18 & 179.992 \\
\hline $\mathrm{H} 29-\mathrm{C} 15-\mathrm{C} 14$ & 119.848 & N18-C19-C9-C8 & 133.06 & H31-C18-C19 & 121.254 & N13-C14-C15-C16 & 179.965 \\
\hline C16- C15-C14 & 120.394 & $\mathrm{C} 2-\mathrm{C} 10-\mathrm{O} 11-\mathrm{H} 26$ & 101.723 & $\mathrm{H} 31-\mathrm{C} 18-\mathrm{C} 17$ & 117.264 & C14-C19-S20-H32 & 72.327 \\
\hline $\mathrm{H} 28-\mathrm{C} 14-\mathrm{C} 15$ & 119.635 & C13-C12-C17-N18 & 179.608 & C19-C18-C17 & 121.482 & C15-C14-N13-C12 & 179.713 \\
\hline $\mathrm{H} 28-\mathrm{C} 14-\mathrm{C} 13$ & 119.694 & C19-N18-C17-C16 & 178.568 & $\mathrm{H} 30-\mathrm{C} 17-\mathrm{C} 18$ & 120.731 & C9-C12-N13-C14 & 179.955 \\
\hline C15-C14-C13 & 120.67 & & & $\mathrm{H} 30-\mathrm{C} 17-\mathrm{C} 16$ & 120.43 & C8-C9-C12-N13 & 179.933 \\
\hline $\mathrm{H} 30-\mathrm{C} 16-\mathrm{C} 17$ & 120.688 & & & C18-C17-C16 & 118.839 & & \\
\hline $\mathrm{H} 30-\mathrm{C} 16-\mathrm{C} 15$ & 120.399 & & & $\mathrm{H} 29-\mathrm{C} 16-\mathrm{C} 17$ & 120.014 & & \\
\hline C17-C16-C15 & 118.912 & & & $\mathrm{H} 29-\mathrm{C} 16-\mathrm{C} 15$ & 120.512 & & \\
\hline C12-C17-N18 & 115.06 & & & C17-C16-C15 & 119.474 & & \\
\hline $\mathrm{C} 12-\mathrm{C} 17-\mathrm{C} 16$ & 120.83 & & & C14-C19-C18 & 120.752 & & \\
\hline N18-C17-C16 & 124.11 & & & C14-C19-S20 & 127.244 & & \\
\hline $\mathrm{H} 27-\mathrm{C} 13-\mathrm{C} 14$ & 119.24 & & & C18-C19-S20 & 112.005 & & \\
\hline $\mathrm{H} 27-\mathrm{C} 13-\mathrm{C} 12$ & 121.781 & & & $\mathrm{H} 28-\mathrm{C} 15-\mathrm{C} 16$ & 116.104 & & \\
\hline $\mathrm{C} 14-\mathrm{C} 13-\mathrm{C} 12$ & 118.979 & & & $\mathrm{H} 28-\mathrm{C} 15-\mathrm{C} 14$ & 120.762 & & \\
\hline C17-C12-C13 & 120.214 & & & C16- C15-C14 & 123.134 & & \\
\hline C17-C12-S20 & 114.008 & & & C19-C14-C15 & 116.32 & & \\
\hline C13-C12-S20 & 125.777 & & & C19-C14-N13 & 132.385 & & \\
\hline C12-S20-C19 & 97.185 & & & C15-C14-N13 & 111.295 & & \\
\hline $\mathrm{H} 31-\mathrm{N} 18-\mathrm{C} 17$ & 122.202 & & & C14-N13-C12 & 131.33 & & \\
\hline H31-N18-C19 & 123.005 & & & $\mathrm{H} 27-\mathrm{C} 12-\mathrm{N} 13$ & 117.554 & & \\
\hline C17-N18-C19 & 114.764 & & & $\mathrm{H} 27-\mathrm{C} 12-\mathrm{C} 9$ & 116.044 & & \\
\hline H32-C19-S20 & 109.889 & & & N13-C12-C9 & 126.402 & & \\
\hline H32-C19-N18 & 107.338 & & & $\mathrm{H} 26-\mathrm{O} 11-\mathrm{C} 10$ & 109.471 & & \\
\hline H32-C19-C9 & 113.911 & & & & & & \\
\hline S20-C19-N18 & 98.942 & & & & & & \\
\hline S20-C19-C9 & 113.811 & & & & & & \\
\hline N18-C19-C9 & 111.791 & & & & & & \\
\hline $\mathrm{H} 26-\mathrm{O} 11-\mathrm{C} 10$ & 109.399 & & & & & & \\
\hline
\end{tabular}

Table 2: Bond angles and dihydral angles for the cyclic form and Schiff base form.

\begin{tabular}{|c|c|c|}
\hline Atom & \multicolumn{2}{|c|}{ Charges } \\
\hline & Cyclic form (A) & Schiff base form (B) \\
\hline N3 & -0.62 & -0.62 \\
\hline N18 & -0.8691 & - \\
\hline N11 13 & -0.5325 & -0.5325 \\
\hline S20 & - & -0.629 \\
\hline
\end{tabular}

Table 3: Net charges on active centers of the cyclic form and Schiff base form.

formation.

By heating the cyclic form (A) (Scheme 1 ) at $\geq 210^{\circ} \mathrm{C}$ an intenseorange yellow crystalline compound is formed, that was supposed to be due to the transformation in 7-(2,3-dihydro-1,3-benzothiazol-2-yl) quinolin-8-ol (D) (Scheme 1) by the loss of a hydrogen molecule from it.

Four significant changes in the IR spectrum of the complexes were observed: (i) the band due to $v(\mathrm{NH})$ mode is absent; (ii) three strong bands at 1504, 1436 and $1397 \mathrm{~cm}^{-1}$, and two bands of medium intensity at 1387 and $1530 \mathrm{~cm}^{-1}$ (benzene and thiazol ring vibrations) [30,31]; (iii) a strong band at $828 \mathrm{~cm}^{-1}$ assignable to the $\mathrm{C}-\mathrm{S}-\mathrm{C}$ linkage; (iv) the $v \mathrm{C}=\mathrm{N}$ band is observed in the oxidized product at $1595 \mathrm{~cm}^{-1}$. In the electronic spectrum of the ligand, two bands are observed at $~ 39850$ and $28580 \mathrm{~cm}^{-1}$. They are fully support the typical spectrum of cyclic from of benzothiszoline and may be attributed to $\sigma-\sigma^{*}$ and $\pi-\pi^{*}$ benzenoid transitions. The position of this band remains unchanged with $\mathrm{pH}$. On the other hand, in the corresponding complexes, an additional band

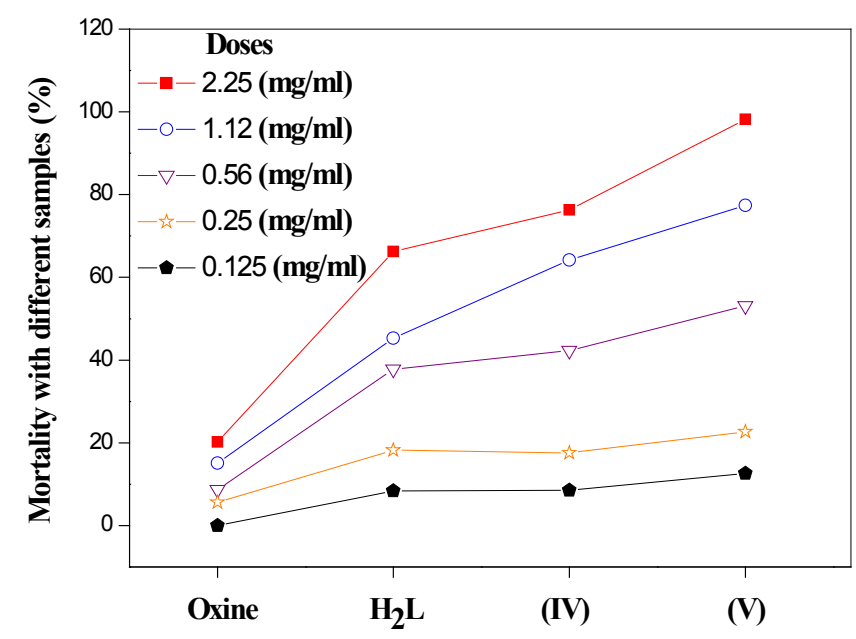

Figure 3: Comparative analysis for the red palm weevil Rhynchophorus ferrugineus (Oliv.) of the samples at different doses.

around $\sim 24400 \mathrm{~cm}^{-1}$ is also observed. This new band may be assigned to either $n-\pi^{*}$ transitions $[7,32]$ or $\pi-\pi^{*}$ transition $[7,32]$ of the double of the azomethine group.

\section{Rearrangement of the ligand in the presence of metal ions}

The reaction of 7-(2,3-dihydro-1,3-benzothiazol-2-yl)quinolin-8- 
Citation: El-Sonbati AZ, Diab MA, El-Bindary AA, Nozha SG, Nassar MI (2014) Evaluation and Rearrangement of Novel Supramolecular 7-(2,3-Dihydro1,3-benzothiazol-2-yl)quinolin-8-ol Complexes and their Biological Effect. J Microbial Biochem Technol S4: 001. doi:10.4172/1948-5948. S4-001

Page 6 of 9

\begin{tabular}{|c|c|c|c|c|c|c|c|c|c|c|}
\hline Compound & $\begin{array}{l}\mathrm{E}_{\text {номо }} \\
\text { (a.u.) }\end{array}$ & $\begin{array}{l}\mathrm{E}_{\text {LuMO }} \\
\text { (a.u.) }\end{array}$ & $\begin{array}{c}\Delta \mathrm{E} \\
\text { (a.u.) }\end{array}$ & $\begin{array}{c}\chi \\
\text { (a.u.) }\end{array}$ & $\begin{array}{c}\eta \\
\text { (a.u.) }\end{array}$ & $\begin{array}{c}\sigma \\
(\text { a.u. })^{-1}\end{array}$ & $\begin{array}{c}\mathrm{Pi} \\
\text { (a.u.) }\end{array}$ & $\begin{array}{c}S \\
(\text { a.u. })^{-1}\end{array}$ & $\begin{array}{c}\omega \\
\text { (a.u.) }\end{array}$ & $\Delta N_{\max }$ \\
\hline Cyclic form (A) & -0.211 & -0.092 & 0.119 & 0.151 & 0.059 & 16.731 & -0.151 & 8.365 & 0.192 & 2.532 \\
\hline Schiff base form (B) & -0.231 & -0.148 & 0.083 & 0.189 & 0.042 & 24.041 & -0.189 & 12.021 & 0.095 & 4.558 \\
\hline
\end{tabular}

Table 4: The calculated quantum chemical parameters for $\mathrm{H}_{2} \mathrm{~L}$.

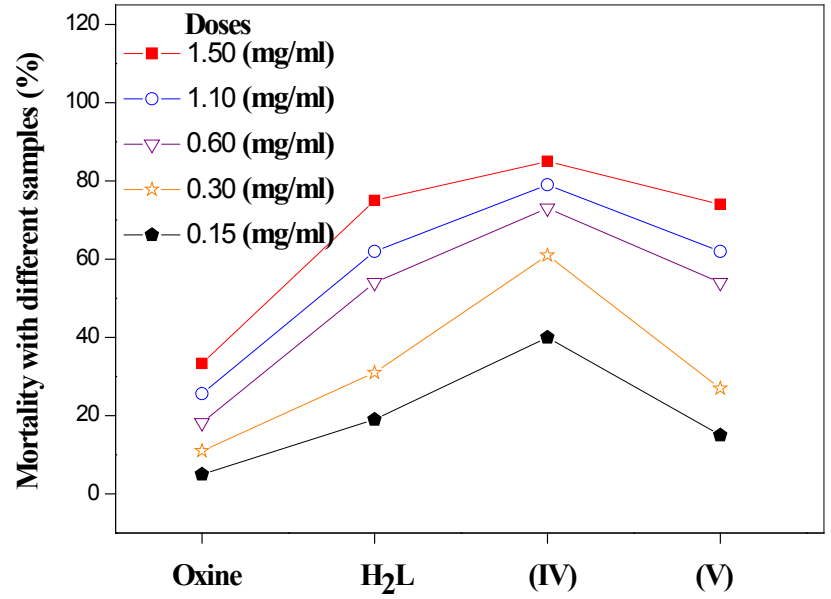

Figure 4: Comparative analysis for the stored food weevils Sitophilus granaria of the samples at different doses.

\begin{tabular}{|l|c|c|c|c|}
\hline \multirow{2}{*}{ Complex } & \multicolumn{4}{|c|}{ Found (Calc.)\% } \\
\cline { 2 - 5 } & C & H & N & S \\
\hline$\left[\mathrm{Cd}(\mathrm{L})\left(\mathrm{OH}_{2}\right)\right]$ & 47.1 & 3.0 & 7.2 & 7.0 \\
$(\mathrm{I})$ & $(47.0)$ & $(2.9)$ & $(6.9)$ & $(7.8)$ \\
\hline$\left[\mathrm{Zn}(\mathrm{L})\left(\mathrm{OH}_{2}\right)\right]$ & 53.1 & 3.2 & 8.1 & 9.1 \\
$(\mathrm{II})$ & $(53.1)$ & $(3.3)$ & $(7.8)$ & $(8.9)$ \\
\hline$\left[\mathrm{Zr}(\mathrm{L}) \mathrm{Cl}_{2}\right]$ & $(41.7)$ & 2.6 & 5.8 & 6.8 \\
$(\mathrm{III})$ & 41.8 & $(2.7)$ & $(6.1)$ & $(7.0)$ \\
\hline$\left[\mathrm{Cu}(\mathrm{L})\left(\mathrm{OH}_{2}\right)\right]$ & 53.7 & 3.5 & 8.3 & 8.7 \\
$(\mathrm{IV})$ & $(53.8)$ & $(3.4)$ & $(7.9)$ & $(9.0)$ \\
\hline$\left[\mathrm{Ni}(\mathrm{L})\left(\mathrm{OH}_{2}\right)_{2}\right]$ & 48.8 & 3.6 & 6.9 & 7.8 \\
$(\mathrm{~V})$ & $(48.9)$ & $(3.6)$ & $(7.1)$ & $(8.1)$ \\
\hline$\left[\mathrm{Co}(\mathrm{L})\left(\mathrm{OH}_{2}\right)_{2}\right]$ & 48.9 & 3.5 & 7.4 & 8.4 \\
$(\mathrm{VI})$ & $(48.9)$ & $(3.6)$ & $(7.1)$ & $(8.1)$ \\
\hline
\end{tabular}

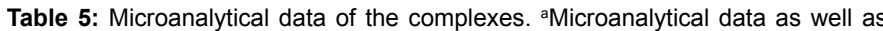
metal estimations are in good agreement with the stoichiometry of the proposed complexes [for molecule structures see Schemes 2-4].

\begin{tabular}{|l|c|c|c|c|c|c|}
\hline Compound & $v(\mathbf{C}=\mathbf{N})$ & $v$ (Aromatic vib.) & $\mathbf{v}(\mathbf{C}-\mathbf{O})$ & $v(\mathbf{M}-\mathbf{S})$ & $v(\mathbf{M}-\mathbf{O})$ & $v(\mathbf{M}-\mathbf{N})$ \\
\hline $\mathrm{H}_{2} \mathrm{~L}^{\mathrm{b}}$ & $\mathrm{C}$ & - & 1272 & - & - & - \\
\hline $\mathbf{( I )}$ & 1585 & 1508,1464 & 1274 & 360 & 510 & 450 \\
\hline $\mathbf{( I I )}$ & 1583 & 1508,1456 & 1270 & 365 & 515 & 455 \\
\hline (III) & 1577 & 1509,1458 & 1273 & 363 & 518 & 460 \\
\hline $\mathbf{( I V )}$ & 1575 & 1510,1460 & 1275 & 1370 & 520 & 410 \\
\hline $\mathbf{( V )}$ & 1572 & 1512,1462 & 1340 & 1375 & 525 & 465 \\
\hline $\mathbf{( V I )}$ & 1574 & 1512,1459 & 1344 & 1377 & 528 & 463 \\
\hline
\end{tabular}

Table 6: Characteristic IR bands $\left(\mathrm{cm}^{-1}\right)$ of the Schiff base and its metal complexes ${ }^{\mathrm{a}}$ ${ }^{a}$ The serial number corresponds to that used in Table 5. ${ }^{b} v(C-S-C)$ link. vib. $=828$ $\mathrm{cm}^{-1},{ }^{\mathrm{c}}$ Cyclic form.

ol $\left(\mathrm{H}_{2} \mathrm{~L}\right)$ with the metal ions investigated in this work are invariably accompanied with the opening of the thiazoline ring and the rearrangement of the ligand to the Schiff base 7-(2,3-dihydro-1,3benzothiazol-2-yl)quinolin-8-ol (B) (Scheme 1). Thus the complexes obtained were of the form $\left[\mathrm{M}(\mathrm{L})\left(\mathrm{OH}_{2}\right)_{\mathrm{n}}\right]$ (where $\mathrm{M}=\mathrm{Cd}, \mathrm{Zn}, \mathrm{Cu}$ at $\mathrm{n}=1$;

\begin{tabular}{|c|c|c|}
\hline Compound & $-\mathbf{O H}$ & $-\mathbf{C}_{6} \mathbf{H}_{4}$ \\
\hline Scheme 1 A & 12.02 & $6.53-7.24$ \\
\hline (I) & 12.12 & $6.33-7.44$ \\
\hline (II) & 11.92 & $6.30-7.46$ \\
\hline
\end{tabular}

Table 7: ${ }^{1} \mathrm{H}$ NMR data of ligand* and its complexes ${ }^{\mathrm{a}}$. ${ }^{\mathrm{T}}$ The serial number corresponds to that used in Table 5. *No signals even weak, of the open ring tautomer (Scheme 1B) can be detected. Note: NH proton signal is observed at $4.18 \mathrm{ppm}$ (Scheme $1 \mathrm{~A})$.

$\mathrm{M}=\mathrm{Co}, \mathrm{Ni}$ at $\mathrm{n}=2)$ and $\left[\mathrm{Zr}(\mathrm{L})(\mathrm{Cl})_{2}\right]$. $\mathrm{L}$ is stands for the conjugate anion of the Schiff base $\left(\mathrm{H}_{2} \mathrm{~L}\right)(\mathrm{B})$.

Reaction of a solution of (A) in DMF:Ethanol (2:1) with $\mathrm{M}\left(\mathrm{CH}_{3} \mathrm{COO}\right)_{2}(\mathrm{M}=\mathrm{Zn}$ or $\mathrm{Cd}), \mathrm{ZrCl}_{4}$ and $\mathrm{MCl}_{2}(\mathrm{M}=\mathrm{Cu}, \mathrm{Co}, \mathrm{Ni})$ with stirring at room temperature yields a dark crystalline complexes (Schemes 2-4). The IR spectra of this complexes show absorptions at $\sim 1590,1510$ and $1460 \mathrm{~cm}^{-1}$ (Table 6) which can be ascribed to imine and aromatic ring vibrations. On the other hand, no C-S-C linkage band (characteristic of the closed ring structure) appears. These results indicate that the metal complexes of the tautomeric Schiff base were obtained.

Important IR bands of the ligand and the complexes have been compared in order to find out bonding sites of the ligand. A broad and strong band at $3360-3060 \mathrm{~cm}^{-1}$, attributable to $v \mathrm{OH}$ and/or $v \mathrm{NH}$ disappears altogether in the complexes, indicating bond formation between metal and phenolic oxygen atom after deprotonation. This is also supported by the disappearance of a series of bands in the vicinity of $2960 \mathrm{~cm}^{-1}$ due to intramolecular hydrogen bonding (Scheme 1) $[11,13,33]$. However, new bands appear at $\sim 1595, \sim 3430$, and 795-815 $\mathrm{cm}^{-1}$, possibly due to $v \mathrm{C}=\mathrm{N}, v(\mathrm{OH})$ and $\delta\left(\mathrm{H}_{2} \mathrm{O}\right)$ of the coordinated azomethine and water molecules in the complexes. The disappearance, in the spectra of all complexes of a peak due to $v(\mathrm{~S}-\mathrm{H})$, indicates the deprotonation of thiolic proton on complex formation [34]. The participation of phenolic oxygen and thiolic sulphur in coordination to the metal ion is further supported by an upward shift [34] in $v(\mathrm{C}-\mathrm{O})$ (phenolic) to extent of 20-30 $\mathrm{cm}^{-1}$ and a downward shift [17-19,34] in $v(\mathrm{C}-\mathrm{S})$ in all the complexes. The major shift of $v(\mathrm{C}-\mathrm{O})$ (phenolic) to higher energy by $\sim 30 \mathrm{~cm}^{-1}$ in the case of $\mathrm{Ni}(\mathrm{II})$ and $\mathrm{Co}$ (II) complexes certainly indicates the presence of phenoxo bridge [35]. The new medium to strong absorption bands at 510-530, 440-470, 360-385 and $\sim 300 \mathrm{~cm}^{-1}$ are assigned to $v(\mathrm{M}-\mathrm{O}), v(\mathrm{M}-\mathrm{N}), v(\mathrm{M}-\mathrm{S})$ and $v(\mathrm{Zr}-\mathrm{Cl})$ modes [36], respectively.

Taking into consideration the previous reports [37] we have attributed a band of medium intensity appearing around $290 \mathrm{~cm}^{-1}$ to $v(\mathrm{Zr}-\mathrm{Cl})$ vibration. The appearing of only one medium intensity band in the above region makes us to corroborate that chlorine atoms in the complex occupy the Trans position. The ligand acts as tridentate and dibasic coordinating to the metal atom via the nitrogen atom of the azomethine group, sulphur and oxygen atoms of thiazoline as evidenced by their spectral data.

\section{Magnetic moments}

The magnetic moments of the complexes (Table 8) were measured at room temperature. On the basis of the magnetic and spectral evidence 
Citation: El-Sonbati AZ, Diab MA, El-Bindary AA, Nozha SG, Nassar MI (2014) Evaluation and Rearrangement of Novel Supramolecular 7-(2,3-Dihydro1,3-benzothiazol-2-yl)quinolin-8-ol Complexes and their Biological Effect. J Microbial Biochem Technol S4: 001. doi:10.4172/1948-5948. S4-001

Page 7 of 9

\begin{tabular}{|c|c|c|c|c|c|c|c|c|c|}
\hline Complex & $\begin{array}{l}\text { Band Position } \\
\left(\mathrm{cm}^{-1}\right)\end{array}$ & Assignment & $\mathrm{Dq}\left(\mathrm{cm}^{-1}\right)$ & $\mathrm{B}\left(\mathrm{cm}^{-1}\right)$ & $\beta$ & $u_{2} / u_{1}$ & LFSF $\left(\mathrm{KJmol}^{-1}\right)$ & $\mu_{\text {eff. }}^{b}(B . M)$ & Geometry \\
\hline IV & - & - & 1960.6 & - & - & - & 140.71 & 1.92 & Tetrahedral \\
\hline \multirow[t]{3}{*}{ V } & 9520 & ${ }^{3} \mathrm{~A}_{2 \mathrm{~g}} \rightarrow{ }^{3} \mathrm{~T}_{2 \mathrm{~g}}(\mathrm{~F})$ & 952.2 & 966 & 0.92 & 1.72 & 136.7 & 3.1 & Octahedral \\
\hline & 16390 & ${ }^{3} \mathrm{~A}_{2 g} \rightarrow{ }^{3} \mathrm{~T}_{1 g}(\mathrm{~F})$ & & & & & & & \\
\hline & 26665 & ${ }^{3} A_{2 g} \rightarrow{ }^{3} T_{1 g}(P)$ & & & & & & & \\
\hline \multirow[t]{3}{*}{ VI } & 8695 & ${ }^{4} \mathrm{~T}_{1 \mathrm{~g}} \rightarrow{ }^{4} \mathrm{~T}_{2 \mathrm{~g}}(\mathrm{~F})$ & 869.5 & 819.3 & 0.84 & 1.97 & 83.2 & 4.46 & Octahedral \\
\hline & 17100 & ${ }^{4} \mathrm{~T}_{1 \mathrm{~g}} \rightarrow{ }^{4} \mathrm{~A}_{2 \mathrm{~g}}(\mathrm{~F})$ & & & & & & & \\
\hline & 21270 & ${ }^{4} \mathrm{~T}_{1 \mathrm{~g}} \rightarrow{ }^{4} \mathrm{~T}_{1 \mathrm{~g}}(\mathrm{P})$ & & & & & & & \\
\hline
\end{tabular}

Table 8: Electronic spectral bands, assignments ligand field parameters for complexes ${ }^{\mathrm{a}}$. ${ }^{\mathrm{T}}$ The serial number corresponds to that used in Table 5 . ${ }^{\mathrm{b}} \mathrm{Per}$ metal ion and measured at room temperature

\begin{tabular}{|c|c|c|c|c|c|c|c|c|c|c|}
\hline Complex & $\mathbf{g}_{\|}$ & $\mathbf{g}_{\perp}$ & $\mathrm{g}_{\text {iso }}$ & $\mathbf{A}_{\mathrm{II}}^{\mathrm{b}}$ & $\mathbf{A}_{\perp}$ & $\mathbf{G}$ & f & $\mathbf{K}_{\mathrm{II}}$ & $\mathbf{K}_{\perp}$ & $\alpha^{2}$ \\
\hline IV & 2.41 & 2.07 & 2.19 & 168 & 25 & 5.7 & 143 & 0.64 & 0.53 & 0.98 \\
\hline
\end{tabular}

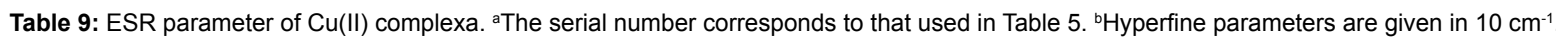

the $\mathrm{Cu}(\mathrm{II})$ complex shows the presence of one unpaired electron (1.92 B.M.). The relatively higher 1.92 B.M. value seems to suggest the relatively high tetrahedral distortion from square planar geometry.

\section{Electron spin resonance}

The ESR spectrum of solid $\mathrm{Cu}(\mathrm{II})$ complex at room temperature is characteristic of a monomer, $\mathrm{d}^{9}$, configuration. The ESR spectrum shows $\mathrm{g}_{\| 1}>\mathrm{g}_{\perp}>2.0023$, suggesting a $\mathrm{d}_{\mathrm{x} 2-\mathrm{y} 2}$ ground state, which is characteristic of a tetrahedral geometry [24]. The g-values are related by the expression [24], $G=\left(g_{\|}-2\right) /\left(g_{\perp}-2\right)$. If $G<4.0$, significant exchange is present. Copper(II) complex shows $\mathrm{G}>4.0$, indicating the presence of distribution from square planar towards tetrahedral configuration.

The g-values of $\mathrm{Cu}(\mathrm{II})$ complex with a ${ }^{2} \mathrm{~B} 1 \mathrm{~g}$ ground state $\left(\mathrm{g}_{\mathrm{Il}}>\mathrm{g}_{\perp}\right)$ may be expressed $[24,38]$ by:

$$
\begin{aligned}
& g_{I I}=2.0023-\left(8 K_{I I}^{2} \lambda_{o} / \Delta E_{\mathrm{xy}}\right) \\
& g_{\perp}=2.0023-\left(2 K_{\perp} \lambda_{o} / \Delta E_{\mathrm{xz}}\right)
\end{aligned}
$$

where $K_{\| l}$ and $K_{\perp}$ are the parallel and perpendicular components respectively of the orbital reduction factor $(\mathrm{K}) . \lambda_{\mathrm{o}}$ is the spin-orbit coupling constant for the free copper. $\Delta \mathrm{E}_{\mathrm{xy}}$ and $\Delta \mathrm{E}_{\mathrm{xz}}$ are the electron transition energies of ${ }^{2} \mathrm{~B}_{1 \mathrm{~g}} \rightarrow{ }^{2} \mathrm{~B}_{2 \mathrm{~g}}$ and ${ }^{2} \mathrm{~B}_{1 \mathrm{~g}} \rightarrow{ }^{2} \mathrm{E}_{\mathrm{g}}$. From the above relations, the orbital reduction factor $\left(\mathrm{K}_{\|}, \mathrm{K}_{\perp}, \mathrm{K}\right)$, which are a measure of covalency $[24,38]$ can be calculated. For an ionic environment, $\mathrm{K}=1$ and for a covalent environment $K<1$, the lower the value of $K$, the greater is the covalent character. Kivelson and Neiman [39] noted that, for an ionic environment, $g_{\| 1}>2.3$ and for a covalent environment $g_{\| 1}<2.3$. Approximate metal-ligand $\sigma$-bond coefficients $\left(\alpha^{2}\right)$, which is defined as the fraction of unpaired electron density located on the copper ion, for this complex was, calculated (Table 9). The empirical factor $\mathrm{f}=\mathrm{g}_{\|} / \mathrm{A}_{\|}$ $\mathrm{cm}^{-1}$ value was considered as a diagnostic of stereochemistry. The $\mathrm{g}_{\|} /$ $\mathrm{A}_{\| 1} \mathrm{~cm}^{-1}$ value (Table 9) shows that the complex (IV) has a tetrahedral geometry, and this is further confirmed by the Symons plot [40].

The electronic spectrum of Co(II) complex showed three absorption bands which may be attributed to the three spin-allowed transitions $8695 \mathrm{~cm}^{-1}\left[{ }^{4} \mathrm{~T}_{1 \mathrm{~g}}(\mathrm{~F}) \rightarrow{ }^{4} \mathrm{~T}_{2 \mathrm{~g}}(\mathrm{~F})\left(v_{1}\right)\right], 17100 \mathrm{~cm}^{-1}\left[{ }^{4} \mathrm{~T}_{1 \mathrm{~g}}(\mathrm{~F}) \rightarrow{ }^{4} \mathrm{~A}_{2 \mathrm{~g}}(\mathrm{~F})\left(v_{2}\right)\right]$ and $2127 \mathrm{~cm}^{-1}\left[{ }^{4} \mathrm{~T}_{1 \mathrm{~g}}(\mathrm{~F}) \rightarrow{ }^{4} \mathrm{~T}_{1 \mathrm{~g}}\left(v_{3}\right)\right]$. Ni(II) complex exhibited three intense bands which are assigned to $9520 \mathrm{~cm}^{-1}\left[{ }^{3} \mathrm{~A}_{2 \mathrm{~g}}(\mathrm{~F}) \rightarrow{ }^{3} \mathrm{~T}_{2 \mathrm{~g}}\left(v_{1}\right)\right], 16390 \mathrm{~cm}^{-1}$ $\left[{ }^{3} \mathrm{~A}_{2 \mathrm{~g}}(\mathrm{~F}) \rightarrow{ }^{3} \mathrm{~T}_{1 \mathrm{~g}}(\mathrm{~F})\left(\mathrm{v}_{2}\right)\right]$ and $26665 \mathrm{~cm}^{-1}\left[{ }^{3} \mathrm{~A}_{2 \mathrm{~g}}(\mathrm{~F}) \rightarrow{ }^{3} \mathrm{~T}_{1 \mathrm{~g}}(\mathrm{P})\left(v_{3}\right)\right]$ transition [41].

The ligand field parameters like ligand field splitting energy (10Dq),
Racah inter-electronic repulsion parameter (B), covalent factor $(\beta)$ and ligand field stabilization energy (LFSE) has been calculated [42] and values compiled in Table 8 . The calculated Dq and CFSE values of all complexes except $\mathrm{Zr}(\mathrm{III}), \mathrm{Zn}(\mathrm{II})$ and $\mathrm{Cd}(\mathrm{II})$ complexes, as well as the $\mathrm{B}$ and $\beta$-values have been calculated only for $\mathrm{Co}(\mathrm{II})$ and $\mathrm{Ni}$ (II) complexes following standard equation $[42,43]$. The B-values are lower than the free ion values, thereby indicating the orbital overlap and delocalization of $d$-orbitals. The $\beta$-values obtained are less than unity commensurate considerable amount of covalent character of the metal-ligand bands $[42,43]$.

\section{Stereochemistry of zirconyl complex}

All these observation were taken together with the wide range of coordination numbers ranging from four to eight, envisages that in the complex (III) exhibit coordination number five.

However, it is known from the available data that the complex (III) belonging to $\mathrm{d}^{0}, \mathrm{~d}^{8}$ and $\mathrm{d}^{10}$ systems have trigonal bipyramidal configuration and only a few have square pyramidal configuration. In view of this finding for the zirconium complex it may be suggested that this complex may exist in trigonal bipyramidal structure.

\section{Thermal analysis}

The temperature range for the dehydration process shows a strong relationship with the binding mode of the water molecules of the respective metal complexes. The elimination of water occurs in two steps. The first step can be attributed to the release of the hydration water molecules in the temperature range $45-55^{\circ} \mathrm{C}$ [44]. In the second step, except for the complex (III), all complexes lose coordinated water at temperature $130-145^{\circ} \mathrm{C}[27,44]$. The thermal decomposition of the anhydrous complexes starts in the temperature range $330-370^{\circ} \mathrm{C}$ and is complete at temperature $560-750^{\circ} \mathrm{C}$. The final decomposition products are metal oxides [13,27]. As results of the dehydration and decomposition, the observed weight losses for all complexes are in good agreement with the calculated values.

\section{Effect of compounds on the red palm weevil Rhynchophorus ferrugineus (Oliv.)}

Listed data in Table 10 concluded that the different novel compounds have been produced lethal effect on the newly emerged adult of the red palm weevil Rhynchophorus ferrugineus. The highest mortality was $98.2 \%$, which obtained due to effect of complex (V). Synchronize the lower percent mortality was 5.2\% after treatment adult 
Citation: El-Sonbati AZ, Diab MA, El-Bindary AA, Nozha SG, Nassar MI (2014) Evaluation and Rearrangement of Novel Supramolecular 7-(2,3-Dihydro1,3-benzothiazol-2-yl)quinolin-8-ol Complexes and their Biological Effect. J Microbial Biochem Technol S4: 001. doi:10.4172/1948-5948. S4-001

Page 8 of 9

\begin{tabular}{|l|c|c|c|c|}
\hline \multirow{2}{*}{ Doses $\mathbf{~ m g / m l}$} & \multicolumn{5}{|c|}{ Mortality with different samples (\%) } \\
\cline { 2 - 5 } & Oxine & $\mathbf{H}_{\mathbf{2}} \mathbf{L}$ & $\mathbf{( I V )}$ & $\mathbf{~}^{*}$ \\
\hline 2.25 & 20.2 & 66.2 & 76.3 & 98.2 \\
\hline 1.12 & 15.1 & 45.3 & 64.2 & 77.4 \\
\hline 0.56 & 8.7 & 37.8 & 42.3 & 53.1 \\
\hline 0.25 & 5.6 & 18.2 & 17.6 & 22.7 \\
\hline 0.125 & - & 8.4 & 8.5 & 12.6 \\
\hline Control & - & - & - & - \\
\hline
\end{tabular}

Table 10: Effect of some new biologically active chemical compounds on the red palm weevil Rhynchophorus ferrugineus (Oliv.). *The serial number corresponds to that used in Table 5 .

\begin{tabular}{|l|c|c|c|c|}
\hline \multirow{2}{*}{ Doses mg/ml } & \multicolumn{4}{|c|}{ Mortality with different samples (\%) } \\
\cline { 2 - 5 } & Oxine & $\mathbf{H}_{\mathbf{2}} \mathbf{L}$ & $\mathbf{( I V )}^{\star}$ & $\mathbf{( V )}^{*}$ \\
\hline 1.5 & 33.3 & 75 & 85 & 74 \\
\hline 1.1 & 25.6 & 62 & 79 & 62 \\
\hline 0.6 & 18.2 & 54 & 73 & 54 \\
\hline 0.3 & 11 & 31 & 61 & 27 \\
\hline 0.15 & 5 & 19 & 40 & 15 \\
\hline Control & - & - & - & - \\
\hline
\end{tabular}

Table 11: Effect compounds on the stored food weevils Sitophilus granaria. *The serial number corresponds to that used in Table 5.

with the compound oxine with concentration $0.25 \mathrm{mg} / \mathrm{ml}$. Meanwhile the higher dose $(2.2 \mathrm{mg} / \mathrm{ml})$ was produced $20.2,66.2$ and $76.3 \%$ of adult mortality after adult was treated with the novel compounds oxine, $\mathrm{H}_{2} \mathrm{~L}$ and complex (IV) respectively. On the other hand the adult mortality was dose dependent, where the mortality percent was increased by increasing dose. In descending order of toxicity the novel compounds were (V), (IV) complexes, $\mathrm{H}_{2} \mathrm{~L}$, and oxine, respectively.

The mode of action of these compounds was neurotoxin effect on the nerve cells of the red palm weevil, Rhynchophorus ferrugineus.

Comparative analysis for the red palm weevil Rhynchophorus ferrugineus (Oliv.) of the samples by using five doses are shown in Figure 3, it is observed that the complex (V) was more biologically active chemical than the other compounds. So it can be concluded that the some complexes exhibits higher biologically active chemical than the free ligand [45].

\section{Effect of compounds on the stored food weevils Sitophilus granary}

The recorded results in Table 11 revealed that different mortality percentage were occurred after adult treatment with other doses from the different novel compounds. Where the higher percent of adult mortality was 33.3, 75.0, 85.0, 74\% after adult was treated with dose 1.6 of oxine, $\mathrm{H}_{2} \mathrm{~L}$, complex (IV) and complex (V), respectively. The lower adult mortalities were 5.0, 19.0, 42.0, 40.0 and $15 \%$ when adult of weevil was treated with the doses, $0.15 \mathrm{mg} / \mathrm{ml}$ by the same previous novel compounds, respectively. In order of toxicity effect in descending manner the chemical compounds were (IV) followed by $\mathrm{H}_{2} \mathrm{~L}$, complex (V) and finally oxine.

Many of the new chemical the mode of action of these compounds was neurotoxin effect on the nerve cells of the weevil, Sitophilus granaria.

Comparative analysis for the stored food weevils Sitophilus granaria of the samples by using five doses are shown in Figure 4, it is observed that the complex (IV) was more biologically active chemical than the other compounds.

\section{Conclusions}

In this work, synthesis and characterization of 7-(2,3-dihydro1,3-benzothiazol-2-yl)quinolin-8-ol $\left(\mathrm{H}_{2} \mathrm{~L}\right)$ and its $\mathrm{Cu}(\mathrm{II}), \mathrm{Co}(\mathrm{II})$, $\mathrm{Ni}(\mathrm{II}), \mathrm{Zn}(\mathrm{II}), \mathrm{Cd}(\mathrm{II})$ and $\mathrm{Zr}(\mathrm{IV})$ complexes have been isolated and characterized. The analytical and physicochemical analysis confirmed the composition and the structure of the newly obtained compounds. The results obtained can be summarized as follows:

i. Elemental analysis, IR and molar conductivity data are used to proof the stoichiometry and formulation of the complexes. All complexes are 1:1 (metal:ligand) stoichiometry and except (I)(III), the $\mathrm{H}_{2} \mathrm{O}$ molecule(s) are coordinated to the metal ion. The data suggest that the $\mathrm{Co}$ (II) and $\mathrm{Ni}(\mathrm{II})$ complexes are binuclear and octahedral dimmers, while the rest are monomeric with square planar/tetrahedral geometries, based on the magnetic data, spectral (ESR and visible) and thermal studies.

ii. The molecular and electronic structures of the investigated ligand $\left(\mathrm{H}_{2} \mathrm{~L}\right)$ [cyclic form (A) and the Schiff base form (B)] have been discussed.

iii. It was found that the Schiff base form (B) more reactive than cyclic form (A).

iv. The spectral studies of the isolated complexes showed that the rearrangement of the benzothiazoline to the Schiff base had occurred.

v. ESR calculations support the characterization of the structures of the complexes geometries.

vi. The lowest mortality was $5.6 \%$ which obtained due to effect of oxine after adult was treated with dose of $0.25 \mathrm{mg} / \mathrm{ml}$.

The mode of action of these compounds was neurotoxin effect on the nerve cells of the red palm weevil, Rhynchophorus ferrugineus.

\section{References}

1. Abou-Dobara MI, El-Sonbati AZ, Morgan ShM (2013) Influence of substituent effects on spectroscopic properties and antimicrobial activity of 5-(4'-substituted phenylazo)-2-thioxothiazolidinone derivatives. World J Microbiol Biotechnol 29: 119-126.

2. El-Sonbati AZ, Diab MA, El-Bindary AA, Abou-Dobara MI, Seyam HA (2013) Supramolecular coordination and antimicrobial activities of constructed mixed ligand complexes. Spectrochim Acta A 104: 213-221.

3. Madapa S, Tusi Z, Batra S (2008) Advances in the syntheses of quinoline and quinoline-annulated ring systems. Current Org Chem 12: 1116-1183

4. Lindoy LF, Livingstone SE (1967) The metal-ion induced rearrangement of 2-(2-pyridyl)benzothiazoline. Inorganica Chimica Acta 1: 365-370.

5. Dhar DN, Taploo CL (1982) Schiff bases and their applications. J Sci Ind Res 41: 501-506.

6. Begum TN, Raju AJ, Reddy GN, Sreeramulu J (2014) Spectroscopic characterization and biological evolution of ortho vanillin pramipexole schiff base metal complexes. Der Pharm Chem 6: 51-58.

7. Garnovskii AD, Nivorozhkin AL, Minkin VI (1993) Ligand environment and the structure of schiff base adducts and tetracoordinated metal-chelates. Coordin Chem Reviews 126: 1-69.

8. El-Sonbati AZ, El-Bindary AA (2000) Stereochemistry of new nitrogen containing aldehydes. $V$. Novel synthesis and spectroscopic studies of some quinoline Schiff bases complexes. Polish J Chem 74: 621-630.

9. Mubarak AT, El-Sonbati AZ, El-Bindary AA, Issa RM, Kera HM (2006) Polymer complexes: supramolecular modeling for determination and identification of the bond lengths in novel polymer complexes from their infrared spectra. Appl Organomet Chem 20: 819-829.

10. Diab MA, El-Bindary AA, El-Sonbati AZ, Salem OL (2012) Supramolecular 
Citation: El-Sonbati AZ, Diab MA, El-Bindary AA, Nozha SG, Nassar MI (2014) Evaluation and Rearrangement of Novel Supramolecular 7-(2,3-Dihydro1,3-benzothiazol-2-yl)quinolin-8-ol Complexes and their Biological Effect. J Microbial Biochem Technol S4: 001. doi:10.4172/1948-5948. S4-001

structure and substituents effect on the spectral studies of dioxouranium(VI) azodyes complexes. J Mol Struct 1007: 11-19.

11. Diab MA, El-Bindary AA, El-Sonbati AZ, Salem OL (2012) Supramolecular structure and substituents effect on the spectral studies of oxovanadium(IV) azodyes complexes. J. Mol. Struct. 1018: 176-184.

12. El-Ghamaz NA, Diab MA, El-Sonbati AZ, Salem OL (2011) D.C. electrical conductivity and conduction mechanism of some azo sulfonyl quinoline ligands and uranyl complexes. Spectrochim Acta A 83: 61-66.

13. Diab MA, El-Sonbati AZ, El-Bindary AA, Barakat AM (2013) Supramolecula spectral studies on metal-ligand bonding of novel quinoline azodyes. Spectrochim Acta A 116: 428-439.

14. El-Sonbati AZ, Diab MA, El-Bindary AA, Abd El-Kader MK (2012) Supramolecular and structural modification on conformational by mixed ligand. Spectrochim Acta A 99: 211-217.

15. Nassar MI, Abdullah MA (2001) Evaluation of Azadirachtin for the contro of the red palm weevil Rhynchophorus ferrugineus (Oliver) (Coleoptera: Curculionidae). J Egypt German Soc Zool 36: 163-173.

16. Cox ML (1993) Red palm weevil, Rhynchophorus ferrugineus, in Egypt. FAOPlant Prot Bull 41: 30-31.

17. Moroney MJ (1956) Facts from Figures (3rd ed.) Penguin Books Ltd., Harmonds Worth. Middlesex.

18. El-Sonbati AZ, Belal AA, El-Gharib MS, Morgan ShM (2012) Supramolecula structure, mixed ligands and substituents effect on the spectral studies of oxovanadium(IV) complexes of bioinorganic and medicinal relevance. Spectrochim Acta A 95: 627-636.

19. El-Sonbati AZ, Diab MA, El-Halawany MM, Salam NE (2010) Polyme complexes: XLXII-interplay of coordination $\pi-\pi$ stacking and hydrogen bonding in supramolecular assembly of [sulpha drug derivatives-N,S:N,O] complexes. Spectrochim Acta A 77: 755-766.

20. El-Sonbati AZ, Diab MA, Belal AAM, Morgan ShM (2012) Supramolecular structure and spectral studies on mixed-ligand complexes derived from ß-diketone with azodye rhodanine derivatives. Spectrochim Acta A 99: 353360.

21. El-Sonbati AZ (1997) Stereochemistry of Uranyl Complexes of New Heterocyclic Nitrogen Containing Aldehydes. I. Novel Relationship for OUO Frequencies Center. Spectroscopy Letter, 30: 459-472.

22. El-Sonbati AZ, Al-Shihri AS, El-Bindary AA (2004) Stereochemistry of new nitrogen containing heterocyclic aldehyde: Part XI. Novel ligational behaviou of quinoline. as chelate ligand toward transition metal ions. Spectrochim Acta A 60: 1763-1768.

23. El-Sonbati AZ, Belal AAM, Abd El-Meksoud SA, El-Boz RA (2012) Supramolecular Structure, Stereochemistry and Substituents Effect on the Spectral Studies of novel ruthenium Complexes. J. Mol. Struct. 1027: 200-206.

24. El-Sonbati AZ, Diab MA, El-Bindary AA, Nozha SG (2011) Structural and characterization of novel copper(II) azodye complexes. Spectrochim Acta A Mol Biomol Spectrosc 83: 490-498.

25. Furniss BS, Hannaford AS, Rogers V, Smith PWG, Tatchell AR (1978) (Eds.) Vogels's Text Book of Practical Organic Chemistry, fourth ed. EIBS Logman Group Ltd., London.

26. El-Bindary AA, El-Sonbati AZ, Diab MA, El-Katori EE, Seyam HA (2014) Potentiometric and thermodynamic studies of some Schiff base derivatives of 4-aminoantipyrine and their metal complexes. Intern. J of Adv Res 2: 493-502.

27. El-Sonbati AZ, Diab MA, El-Bindary AA, Morgan ShM (2014) Supramolecular spectroscopic and thermal studies of azodye complexes. Spectrochim Acta A 127: 310-328.
28. El-Ghamaz NA, El-Sonbati AZ, Diab MA, El-Bindary AA, Awad MK, et al. (2014) Dielectrical, conduction mechanism and thermal properties of rhodanine azodyes. Mater Sci Semicond Proc 19: 150-162.

29. El-Ghamaz NA, Ghoneim MM, El-Sonbati AZ, Diab MA, El-Bindary AA, et al. (2014) Synthesis and optical properties studies of antipyrine derivatives thin films. J Saudi Chem Soc.

30. Tasal E, Kumalar M (2012) Structure and vibrational spectra of 6-(4-fluorobenzoyl)-3-(2-(4-methylpiperazin-1-yl)-2-oxoethyl)benzo[d]thiazol2(3H)-one molecule. Spectrochim Acta A 96: 548-562.

31. Sidir I, Sidir YG, Tasal E, Ögretir C (2010) Ab initio Hartree-Fock and density functional theory investigations on the conformational stability, molecular structure and vibrational spectra of 3-(2-(4-methylpiperazin-1-yl)-2-oxoethyl) benzo[d]thiazol-2(3H)-one. J Mol Struc 980: 230-244.

32. El-Ghamaz NA, El-Sonbati AZ, Diab MA, El-Bindary AA, Seyam HA (2013) Optical properties of thermally evaporated 4-(4-nitrobenzalideneamino) antipyrine Schiff base thin films. Solid State Sci 19: 19-26.

33. El-Ghamaz NA, El-Mallah HM, El-Sonbati AZ, Diab MA, El-Bindary AA, et al. (2013) Optical properties studies on metal-ligand bonding of novel quinoline azodyes thin films. Solid State Sci. 22: 56-64.

34. El-Bindary AA (1998) Novel Synthesis, Spectroscopic Studies and Rearrangement of 2-(Fluorenone)benzothiazoline in the Presence of Meta lons. Synth React Inorg Met Org Chem 28: 1743-1757.

35. Li XY, Wu YQ, Gu DD, Gan FX (2009) Optical characterization and blu-ray recording properties of metal(II) azo barbituric acid complex films. Mater Sci Engin B 158: 53-57.

36. Percy GC, Thornton DA (1972) N-aryl salicylaldimine complexes: Infrared and PMR spectra of the ligands and vibrational frequencies of their metal (II) chelates. J Inorg Nucl Chem 34: 3357-3367.

37. Prashar P, Tandon JP, Less J (1968) Zirconium(IV) complexes with Schiff bases derived from salicylaldehyde and hydroxyalkylamine. Common Metals 15: 219-226.

38. El-Sonbati AZ, Diab MA, El-Halawany MM, Salam NE (2010) Polyme complexes. XLXI. Supramolecular spectral studies on metal-ligand bonding of novel rhodanine sulphadrugs hydrazone. Mater Chem and Phys 123: 439-449.

39. Kivelson D, Neiman R (1961) ESR studies on the bonding in copper complexes. J Chem Phys 35: 149-155.

40. Symons MCR (1963) Identification of organic free radicals by electron spin resonance. Adv Phys Org Chem 1: 283-363.

41. Raman N, Ravichandran S, Thangaraja C (2004) Copper(II), cobalt(II), nickel(II) and zinc(II) complexes of Schiff base derived from benzil-2,4 dinitrophenylhydrazone with aniline. J Chem Sci 116: 215-219.

42. El-Sonbati AZ, El-Bindary AA, Mabrouk SM, Ahmed RM (2001) Synthesis and characterization of copper(II), nickel(II), cadmium(II), cobalt(II) and zinc(II) complexes with 2-benzoyl-3-hydroxy-1-naphthylamino-3-phenyl-2-propen-1 on. Spectrochim Acta A 57: 1751-1757.

43. El-Bindary AA, El-Sonbati AZ, Ahmed RM (2002) Coordination modes of nove rhodanine azodye complexes. Spectrochim Acta A 58: 333-339.

44. Arun V, Mathew S, Robinson PP, Jose M, Nampoori VPN, Yusuff KKM (2010) The tautomerism, solvatochromism and non-linear optical properties of fluorescent 3-hydroxyquinoxaline-2-carboxalidine-4-aminoantipyrine. Dyes and Pigments 87: 149-157.

45. Hanif M, Chohan ZH (2013) Design, spectral characterization and biological studies of transition metal(II) complexes with triazole Schiff bases. Spectrochim Acta A 104: 468-476 